\title{
Pengaruh Kompetensi Kewirausahaan dan Pengawasan Manajemen terhadap Perkembangan Perusahaan PT Ekuator Swarna Sekuritas Cabang Medan
}

\author{
*Claudie ${ }^{1}$, Pesta Gultom ${ }^{2}$, \\ ${ }^{12}$ Program Studi Manajemen, STIE Eka Prasetya, Indonesia, ${ }^{2}$ Dosen Program Studi \\ Manajemen, STIE Eka Prasetya, Indonesia \\ *(Email: claudie.tiofanny@gmail.com )
}

\begin{abstract}
This study aims to determine how much influence Entrepreneurship Competence and Management Supervision on the Development of PT Ekuator Swarna Sekuritas Medan Branch. The research methodology used is descriptive and explanatory survey methods. The population in this study were 1003 customers of PT Ekuator Swarna Sekuritas Medan Branch. The technique of determining the number of samples in this study was determined using the Slovin formula and amounted to 91 respondents. The $t$ test results show that the Entrepreneurial Competence variable is positively and significantly influenced by the Development of PT Ekuator Swarna Sekuritas Medan Branch and the Management Control variable has a positive and significant effect on the development of PT Ekuator Swarna Sekuritas Medan Branch. Simultaneously affect the dependent variable (Company Development)
\end{abstract}

Keywords: Entrepreneurship Competence, Management Oversight, Development Company

\begin{abstract}
ABSTRAK
Penelitian ini bertujuan untuk mengetahui seberapa besar pengaruh Kompetensi Kewirausahaan dan Pengawasan Manajemen terhadap Pengembangan PT Ekuator Swarna Sekuritas Cabang Medan. Metodologi penelitian yang digunakan adalah metode deskriptif dan explanatory survey. Populasi dalam penelitian ini adalah pelanggan PT Ekuator Swarna Sekuritas Cabang Medan yang berjumlah 1003 responden. Teknik penentuan jumlah sampel dalam penelitian ini ditentukan dengan menggunakan rumus Slovin dan berjumlah 91 responden. Hasil uji t menunjukkan bahwa variabel Kompetensi Kewirausahaan dipengaruhi secara positif dan signifikan oleh Pengembangan PT Ekuator Swarna Sekuritas Cabang Medan dan variabel Pengendalian Manajemen berpengaruh positif dan signifikan terhadap Perkembangan PT Ekuator Swarna Sekuritas Cabang Medan. Secara simultan mempengaruhi variabel dependen (Perkembangan Perusahaan)
\end{abstract}

Kata Kunci : Kompetensi Kewirausahaan, Pengawasan Manajemen, Perkembangan Perusahaan 


\section{PENDAHULUAN}

PT Ekuator Swarna Sekuritas Cabang Medan merupakan sebuah perusahaan yang bergerak di bidang pialang. Pada perusahaan ini terjadi penurunan perkembangan perusahaan yang terlihat dari menurunnya jumlah nasabah baru perusahaan sehingga berdampak pada pendapatan perusahaan juga mengalami penurunan. Data jumlah nasabah baru pada tahun 2016 mengalami penurunan sebesar 11.4\%, tahun 2017 mengalami penurunan sebesar $18.75 \%$, tahun 2018 mengalami penurunan sebesar $12.28 \%$ dan tahun 2019 mengalami penurunan sebesar $8.23 \%$. Hal ini mencerminkan perusahaan mengalami penurunan perkembangan pada setiap tahunnya sedangkan perusahaan menetapkan target pencapaian nasabah baru sebesar 5\% per tahunnya.. Banyak keluhan dari nasabah bahwa nasabah mengelami kekecewaan terhadap sistem layanan yang diberikan.

Agar mencapai kesuksesan karir di dalam suatu bisnis tentunya tidaklah mudah, ada banyak hal yang harus diketahui dan dikuasai oleh pelaku bisnis tersebut. Menurut Airifn (2010:98), Kompetensi Kewirausahaan adalah kemampuan mengambil faktor-faktor produksi yang digunakan untuk memproduksi barang dan jasa baru. Kompetensi wirausaha pada perusahaan ini masih belum dalam keadaan baik. Dimana banyaknya karyawan maupun atasan bukan mempunyai pendidikan maupun pengalaman dalam bidang pialang sehingga kesulitan dalam mengatasi keluhan dari nasabah atas kekecewaan yang dirasakan oleh mereka. Adapun pilihan sertifikasi pendidikan yang harus dimiliki oleh pegawai yang bekerja di bidang pialang adalah WPPE (Wakil Perantara Perdagangan Efek), WPEE (Wakil Penjamin Emisi Efek) dan WMI (Wakil Manajer Investasi).

Terselenggaranya pengawasan dalam sebuah perusahaan dipercaya dapat membantu menilai kinerja suatu institusi dan memperbaiki kinerja sebuah perusahaan. Oleh karena itu dalam setiap perusahaan diharuskan melakukan sistem pengawasan secara rutin. Menurut Handoko (2014:367), Pengawasan adalah kegiatan menemukan keseimbangan antara pengawasan organisasi dan kebebasan pribadi atau mencari tingkat pengawasan yang tepat.. Fungsi pengawasan dapat dilakukan setiap saat, baik selama proses manajemen atau administrasi berlangsung maupun setelah berakhir untuk mengetahuai tingkat pencapaian tujuan suatu organisasi atau kerja. Fungsi pengawasan dilakukan terhadap perencanaan dan kegiatan pelaksanaannya. Kegiatan pengawasan sebagai fungsi manajemen bermaksud untuk mengetahui tingkat keberhasilan dan kegagalan yang terjadi setelah perencanaan dibuat dan dilaksanakan. Keberhasilan perlu dipertahankan dan jika mungkin ditingkatkan dalam perwujudan manajemen berikutnya dilingkungan suatu organisasi atau unit kerja tertentu. Sebaliknya setiap kegagalan harus diperbaiki dengan menghindari penyebabnya baik dalam menyusun perencanaan maupun pelaksanaannya.

Kurangnya pengawasan manajemen yang dilaksanakan pada perusahaan ini meningkatkan tingkat kesalahan sehingga memicu kekecewaan nasabah bahkan terkadang merugikan nasabah. Hal tersebut disebabkan oleh kurangnya arahan atasan terhadap perbaikan masalah dengan nasabah sehingga karyawan sulit mencari jalan keluar. Pengawasan manajemen yang diterapkan di perusahaan juga tergolong masih kurang objektif dan fleksibel serta tidak dilakukan di seluruh divisi kerja. Diberlakukannya sistem special fee khusus untuk kerabat/orang dekat pihak manajemen tanpa memandang keuntungan dan kerugian yang dialami perusahaan menyebabkan pengawasan menjadi kurang objektif. Atasan juga 
bersikeras memberlakukan aturan tanda tangan basah untuk form reset password dan pin dimana hal tersebut dinilai tidak fleksibel dan menyulitkan nasabah yang berada di luar kota. Pengawasan yang tidak dilakukan di seluruh devisi kerja dari atasan yang mengimplementasikan sistem pengawasan berbentuk laporan kerja kepada devisi back office sedangkan untuk devisi marketing tidak diberlakukan sistem pengawasan apapun. Berdasarkan uraian latar belakang diatas tersebut, maka peneliti tertarik dengan judul "Pengaruh Kompetensi Kewirausahaan dan Pengawasan Manajemen terhadap Perkembangan Perusahaan PT Ekuator Swarna Sekuritas Cabang Medan”.

\section{Tujuan Penelitian}

Berdasarkan perumusan masalah tersebut, penelitian ini dilakukan dengan tujuan ialah :

1. Untuk mengetahui pengaruh Kompetensi Kewirausahaan terhadap Perkembangan Perusahaan PT Ekuator Swarna Sekuritas Cabang Medan.

2. Untuk mengetahui pengaruh Pengawasan Manajemen terhadap Perkembangan Perusahaan PT Ekuator Swarna Sekuritas Cabang Medan.

Untuk mengetahui pengaruh Kompetensi Kewirausahaan dan Pengawasan Manajemen terhadap Perkembangan Perusahaan PT Ekuator Swarna Sekuritas Cabang Medan.

\section{KAJIAN LITERATUR}

\subsection{Perkembangan Perusahaan}

Menurut Widaningsih dan Ariyanti (2018:90), "Pengembangan Usaha adalah tugas dan proses persiapan analistis tentang peluang pertumbuhan potensial, dukungan dan pemantauan pelaksanaan peluang pertumubuhan usaha tetapi tidak termasuk keputusan tentang strategi dan implementasi dari peluang pertumbuhan usaha."

Menurut Setyorini (2019:66), "Pengembangan Usaha adalah mengatur proses kegiatan usaha, produksi, pemasaran, penjualan, perluasan usaha untuk mencapai tujuan."

Menurut Mahmud (2014:167), "Pengembangan Usaha adalah perdagangan yg dilakukan oleh sekelompok orang yg terorganisasi untuk mendapatkan laba dengan memproduksi dan menjual barang atau jasa untuk memenuhi kebutuhan konsumen".

Menurut Sudjatmoko (2009:91), "Pengembangan Usaha adalah kesesuaian dnagn manajemen yang dapat dikuasai serta selalu harus mengembangkan kreativitas dan inovasi." Menurut Subagyo (2010:29), "Pengembangan Usaha berari usaha yang akan dibangun merupakan bagian dari entitas usaha yangs udah ada sebelumnya". Menurut Primyastanto (2016:6), "Usaha adalah suat upaya dalam memenuhi kebutuhan dengan cara melakukan kegiatan yang menghasilkan baeang maupun jasa." Menurut definisi para ahli di atas, maka kesimpulannya pengembangan usaha adalah istilah yang sering mengacu pada pengaturan dan mengelola hubungan strategis dan aliansi dengan yang lain. 


\subsection{Kompetensi Kewirausahaan}

Menurut Arifin (2010:98), "Kompetensi Kewirausahaan adalah kemampuan mengambil faktor-faktor produksi yang digunakan untuk memproduksi barang dan jasa baru." Menurut Anwar (2014:46), "Kompetensi Kewirausahaan adalah seseorang yang memiliki ilmu pengetahuan, keterampilan dan kualitas individu yang meliputi sikap, motivasi, nilai serta tingkah laku yang diperlukan untuk melaksanakan epkerjaan atau kegiatan.” Menurut Priansa (2016:254), "Kompetensi Kewirausaha adalah peta kapasitas pegawai atas atribut pekerjaan yang diembannya yang merupakan kumpulan dari kemampuan, keterampilan, kematangan, pengalaman, keefektifan, keefisienan, dan kesuksesan dalam mengemban tanggung jawab pekerjaan."

Menurut Wibowo (2014:271), "Kompetensi Kewirausaha adalah suatu kemampuan untuk melaksanakan atau melakukan suatu pekerjaan atau tugas yang dilandasi atas keterampilan dan pengetahuan serta didukung oleh sikap kerja yang dituntut oleh pekerjaan tersebut." Menurut Sedarmayanti (2015:126), "Kompetensi Kewirausaha diartikan sebagai kecakapan, keterampilan, kemampuan."

Dari beberapa pengertian di atas, dapat disimpulkan kompetensi adalah kemampuan karyawan dalam melaksanakan pekerjaannya dengan baik sesuai dengan kemampuan yang dimilikinya serta sebuah pernyataan terhadap apa yang seseorang harus lakukan ditempat kerja untuk menunjukan pengetahuannya, keterampilannya dan sikap sesuai dengan standar yang dipersyaratkan.

\subsection{Teori Pengawasan Manajemen}

Menurut Handoko (2014:367), "Pengawasan adalah kegiatan menemukan keseimbangan antara pengawasan organisasi dan kebebasan pribadi atau mencari tingkat pengawasan yang tepat."

Menurut Kadarisma (2012:171), "Pengawasan sumber daya manusia merupakan kegiatan yang dilakukan untuk mengendalikan pelaksanaan tugas atau pekerjaan yang dilakukan oleh seseorang, agar proses pekerjaan tersebut sesuai dengan hasil yang diinginkan." Menurut Siswandi (2011:85), "Pengawasan merupakan fungsi manajemen yang sangat penting. Pengawasan sangat diperlukan agar tujuan yang ditetapkan dapat dicapai secara efektif dan efisien." Menurut Torang (2016:176), "Pengawasan merupakan proses dasar yang secara esensial tetap diperlukan bagaimana pun rumit dan luasnya ruang organisasi."

Menurut Yuniarsih dan Suwatno (2016:94), "Pengawasan adalah upaya untuk mencapai produktivitas organisasi, dengan efektivitas dan efisiensi yang tinggi dalam rangka mengembangkan karya-karya inovatif." Berdasarkan teori di atas bahwa Pengawasan dalam m suatu organisasi atau perusahaan memiliki peranan penting baik pengawasan internal maupun eksternal. Melalui aktivitas pengawasan diharapkan dapat segera diketahui apabila terjadi penyimpangan dalamkeberjalanan manajemen organisasi yang tidak sesuai dengan perencanaan yang telah ditentukan. 
Berdasarkan uraian diatas dapat disimpulkan bahwa kerangka pemikiran adalah sebagai berikut :

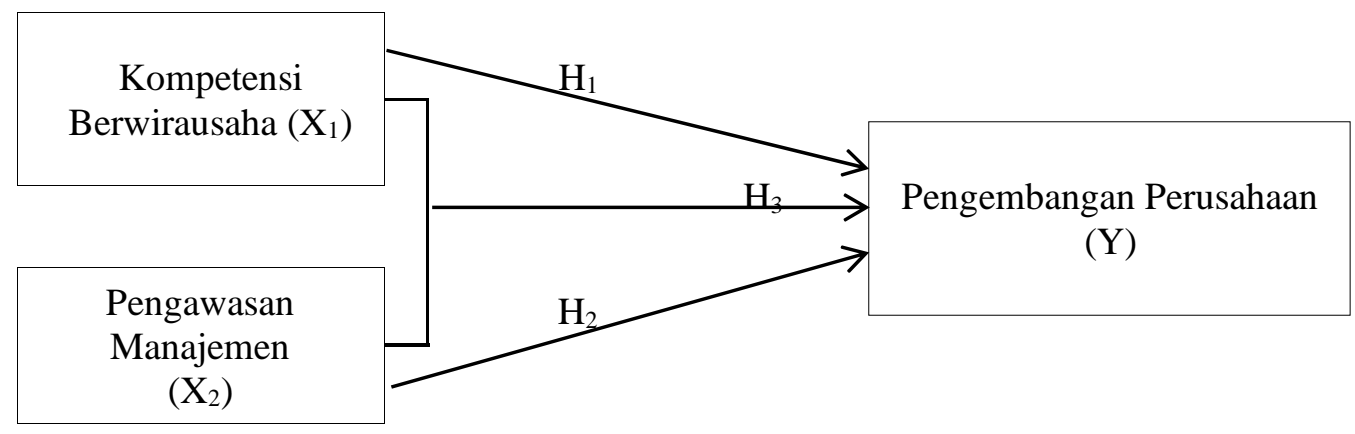

Gambar 1. Kerangka Berfikir

\section{METODE PENELITIAN}

Jenis data yang digunakan dalam penelitian ini terdiri dari data kuantitatif dan kualitatif. Sumber data yang digunakan dalam penelitian ini adalah data primer dan sekunder. Peneliti mengambil populasi dalam penelitian ini sebanyak 1003 nasabah. Jumlah sampel dalam penelitian ini adalah sebanyak 91 nasabah. Teknik sampling yang digunakan adalah simple random sampling. Teknik pengumpulan data yang digunakan dalam penelitian ini meliputi studi pustaka, wawancara dan interview.

Table 1. Definisi Operasional dan Pengukuran Variabel

\begin{tabular}{|c|c|c|c|}
\hline Variabel & Definisi & Indikator & $\begin{array}{c}\text { Skala } \\
\text { Pengukuran }\end{array}$ \\
\hline \multirow[t]{2}{*}{$\begin{array}{c}\text { Kompetensi } \\
\text { Kewirausahaan } \\
\left(\mathrm{X}_{1}\right)\end{array}$} & $\begin{array}{l}\text { Kompetensi Kewirausahaan } \\
\text { adalah kemampuan mengambil } \\
\text { faktor-faktor produksi yang } \\
\text { digunakan untuk memproduksi } \\
\text { barang dan jasa baru." }\end{array}$ & $\begin{array}{l}\text { 1. Kompetensi Berprestasi } \\
\text { 2. Kompetensi Memimpin } \\
\text { 3. Kompetensi Merencanakan } \\
\text { Bisnis }\end{array}$ & Skala Likert \\
\hline & Sumber : Arifin (2010:98) & Sumber : Arifin (2010:98) & \\
\hline \multirow[t]{2}{*}{$\begin{array}{l}\text { Pengawasan } \\
\qquad\left(\mathrm{X}_{2}\right)\end{array}$} & $\begin{array}{l}\text { Pengawasan adalah kegiatan } \\
\text { menemukan keseimbangan } \\
\text { antara pengawasan organisasi dan } \\
\text { kebebasan pribadi atau mencari } \\
\text { tingkat pengawasan yang tepat. }\end{array}$ & $\begin{array}{l}\text { 1. Perubahan Lingkungan } \\
\text { Organisasi } \\
\text { 2. Kesalahan - kesalahan } \\
\text { 3. Kebutuhan manajer untuk } \\
\text { mendelegasikan wewenang }\end{array}$ & Skala Likert \\
\hline & Sumber : Handoko (2014:367) & $\begin{array}{ll}\text { Sumber } \quad: & \text { Handoko } \\
(2014: 373-374) & \end{array}$ & \\
\hline
\end{tabular}




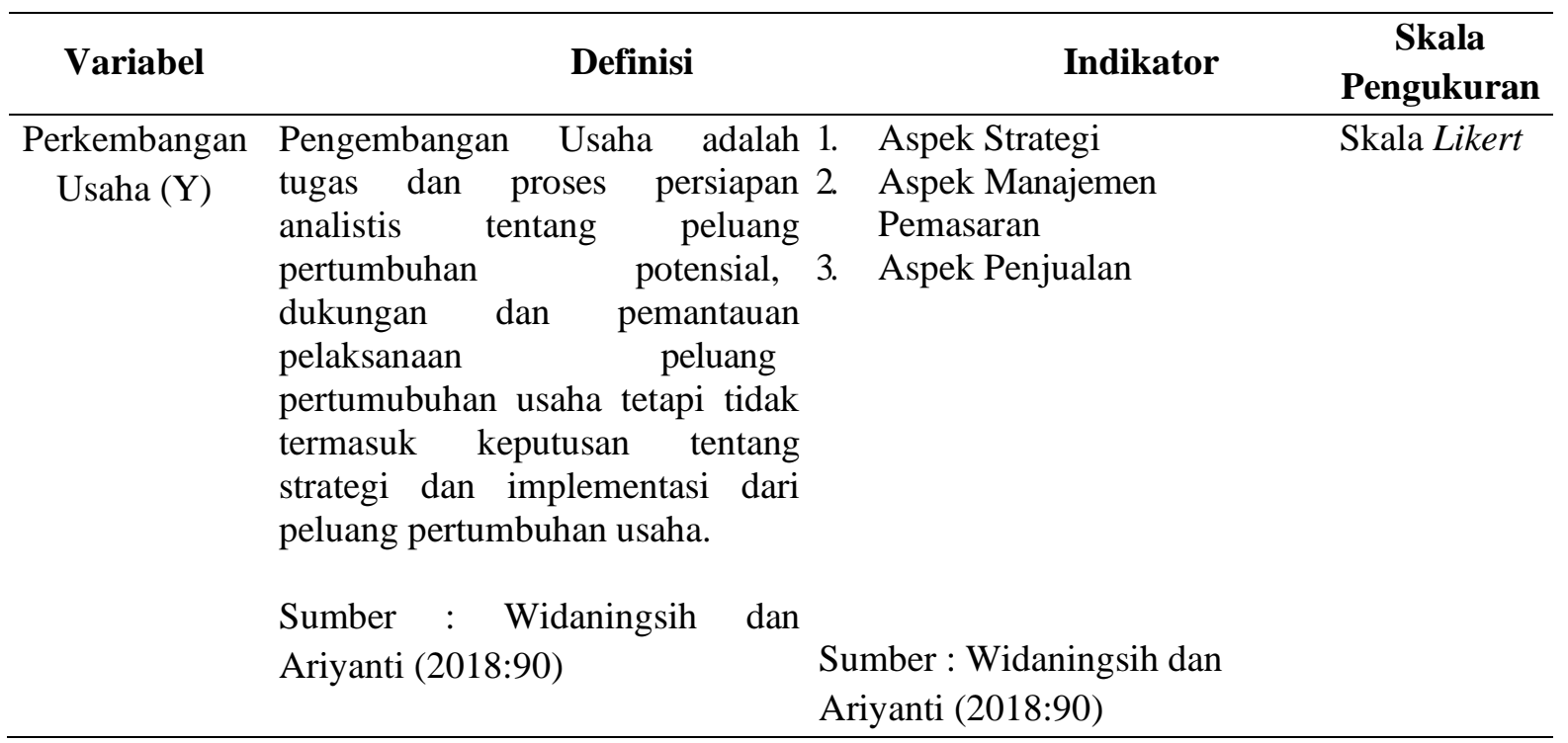

\section{Analisis Regresi Linear Berganda}

Analisis regresi berganda untuk mengetahui pengaruh dua atau lebih variabel bebas $(\mathrm{X} 1,2,3, \ldots, \mathrm{n})$ terhadap variabel terikat $(\mathrm{Y})$. Rumusnya sebagai berikut :

Keterangan :

$$
\mathbf{Y}=\mathbf{a}+\mathbf{b}_{1} \mathbf{X} 1+\mathbf{b}_{2} \mathbf{X}_{2}+\mathbf{e}
$$

\begin{tabular}{|c|c|}
\hline Y & $=$ Perkembangan Usaha (dependent variabel) \\
\hline$x_{1}$ & $=$ Kompetensi (independent variabel) \\
\hline$x_{2}$ & $\begin{array}{l}=\text { Pengawasan }(\text { independent } \text { variabel }) \\
=\text { Konstanta }\end{array}$ \\
\hline $\begin{array}{l}b_{1}, b_{2} \\
e\end{array}$ & $\begin{array}{l}=\text { Koefisien regresi variabel independen } \\
=\text { Kesalahan penduga }(\text { vang tidak terungkap }=5 \%)\end{array}$ \\
\hline
\end{tabular}

\section{HASIL DAN PEMBAHASAN}

\section{Uji Validitas}

Hasil pengujian validitas untuk variabel bebas dan variabel dalam penelitian ini yaitu sebagai berikut :

Tabel 2. Hasil Uji Validitas

\begin{tabular}{cccccc}
\hline No & $\mathbf{r}_{\text {hitung }}$ & $\mathbf{r}_{\text {hitung }}$ & $\mathbf{r}_{\text {hitung }}$ & $\mathbf{r}_{\text {tabel }}$ & Keterangan \\
\hline 1. & 0,652 & 0,622 & 0,632 & 0,361 & Valid \\
2. & 0,564 & 0,632 & 0,719 & 0,361 & Valid \\
3. & 0,617 & 0,517 & 0,673 & 0,361 & Valid \\
4. & 0,681 & 0,618 & 0,689 & 0,361 & Valid \\
5. & 0,575 & 0,729 & 0,657 & 0,361 & Valid \\
6. & 0,575 & 0,577 & 0,565 & 0,361 & Valid \\
\hline
\end{tabular}

Sumber : Hasil Penelitian, 2020 (Data diolah)

Masing-masing pernyataan memililiki nilai $r_{\text {hitung }}>r_{\text {tabel }}(0,361)$ bahwa semua pernyataan atau kuesioner untuk variabel dinyatakan valid.

\section{Uji Reliabilitas}

Berikut hasil pengujian reliabilitas terhadap variabel yang digunakan dalam penelitian 
yaitu :

Tabel 3.Uji Realibilitas Variabel

\begin{tabular}{lcc}
\hline \multicolumn{1}{c}{ Variabel } & Jumlah Pernyataan & Cronbach's Alpha \\
\hline Kompetensi Kewirausaha & .717 & 6 \\
Pengawasan Manajemen & .674 & 6 \\
Pengembangan Usaha & .696 & 6 \\
\hline
\end{tabular}

Sumber : Hasil Penelitian, 2020 (Data diolah)

Tabel 3 menunjukan variabel memiliki nilai Cronbach's Alpha sebesar 0,738 > 0,6 bahwa variabel kuesioner untuk variabel dalam penelitian ini dinyatakan reliabel.

\section{Uji Normalitas}

Berikut ini adalah hasil uji normalitas dengan analisis grafik histogram dan normal P Plot.

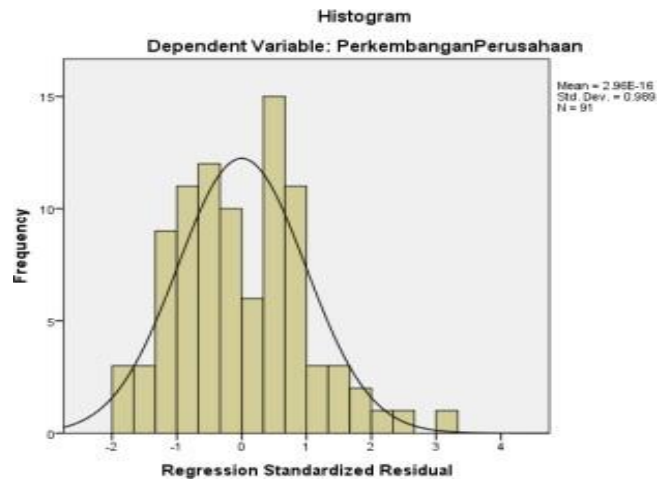

Sumber : Hasil Penelitian, 2020 (Data diolah)

Gambar 2. Grafik Histogram

Gambar 2 menunjukkan bahwa grafik histogram mempunyai data riil membentuk garis kurva cenderung simetri tidak melenceng ke kiri atau pun ke kanan, maka dapat dikatakan data berdistribusi normal.

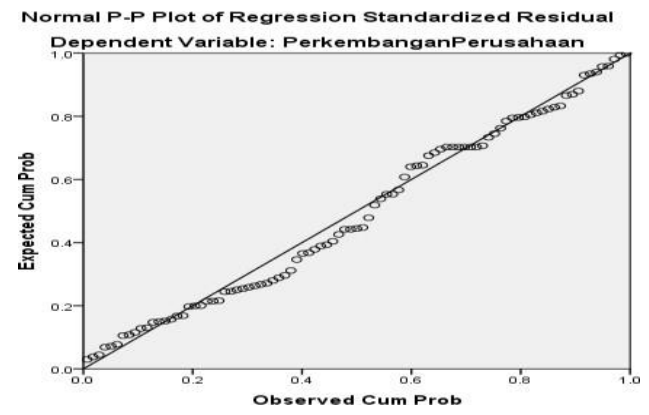

Sumber : Hasil Penelitian, 2020 (Data diolah)

Gambar 3. Grafik Normal Probaility Plot

Gambar 3. Grafik Normalitas P-P Plot, terlihat data menyebar di sekitar garis diagonal dan data menyebar sebagian besar mendekati garis diagonal sehingga dapat disimpulkan data berdistribusi normal. 
Hasil uji One Kolmogrov Smirnov dapat dilihat pada tabel 4.

Tabel 4 Hasil Uji Normalitas

One-Sample Kolmogorov-Smirnov Test

\begin{tabular}{llr}
\hline $\mathrm{N}$ & & Unstandardized Residual \\
\hline & Mean & 91 \\
Normal Parameters ${ }^{\mathrm{a}, \mathrm{b}}$ & Std. Deviation & $0 \mathrm{E}-7$ \\
& Absolute & 4.03163556 \\
& Positive & .080 \\
Most Extreme Differences & Negative & .080 \\
& & -.051 \\
Kolmogorov-Smirnov Z & & .759 \\
Asymp. Sig. (2-tailed) & & .613 \\
\hline
\end{tabular}

a. Test distribution is Normal.

b. Calculated from data.

Sumber : Hasil Penelitian, 2020 ( data diolah)

Tabel 4 menunjukkan nilai signifikan yang diperoleh sebesar 0,613>0,05. Dapat disimpulkan bahwa data tersebut menunjukkan data berdistribusi normal.

\section{Uji Multikolinieritas}

Hasil perhitungan multikolinearitas dapat dilihat berikut ini

Tabel 5. Uji Multikolonieritas Coefficients ${ }^{\mathrm{a}}$

\begin{tabular}{|c|c|c|c|}
\hline \multirow{2}{*}{\multicolumn{2}{|c|}{ Model }} & \multicolumn{2}{|c|}{ Collinearity Statistics } \\
\hline & & Tolerance & VIF \\
\hline \multirow[t]{3}{*}{1} & (Constant) & & \\
\hline & KompetensiKewirausahaan & .842 & 1.187 \\
\hline & PengawasanManajemen & .842 & 1.187 \\
\hline
\end{tabular}

a.Dependent Variable: PerkembanganPerusahaan Sumber : Hasil Penelitian, 2020 ( Data diolah )

Tabel 5. menunjukkan masing-masing variabel bebas sebesar 0,842 >0,01, sedangkan nilai VIF variabel bebas sebesar $1,187<10$ bahwa tidak terjadi multikolinearitas dalam penelitian ini. 


\section{Uji Heteroskedastisitas}

Hasil uji heteroskedastisitas dapat dilihat pada gambar berikut

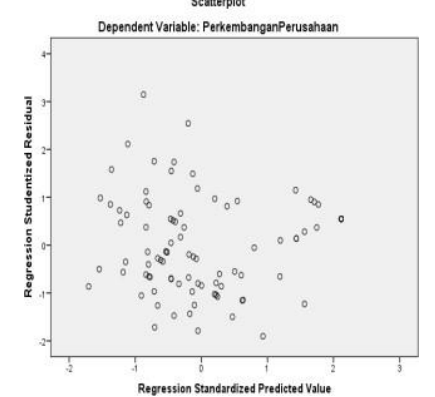

Sumber : Hasil Penelitian, 2020 (Data diolah)

Gambar 4. Grafik Heteroskedastisitas

Gambar 4. menunjukkan data menyebar dengan pola yang tidak jelas baik di atas maupun di bawah angka nol (0) pada sumbu Y, tidak berkumpul di satu tempat, sehingga dari grafik scatterplot dapat di simpulkan bahwa tidak terjadi heteroskedastisitas pada model regresi dalam penelitian ini.

\section{Analisis Regresi Linear Berganda}

Hasil analisis regresi linear berganda dalam penelitian ini yaitu :

Tabel 6. Hasil Analisis regresi Linear Berganda Coefficients ${ }^{\mathrm{a}}$

\begin{tabular}{|c|c|c|c|c|c|c|}
\hline \multirow{2}{*}{\multicolumn{2}{|c|}{ Model }} & \multicolumn{2}{|c|}{$\begin{array}{c}\text { Unstandardized } \\
\text { Coefficients } \\
\text { Std. }\end{array}$} & \multirow{2}{*}{$\begin{array}{c}\text { Standardized } \\
\text { Coefficients } \\
\text { Beta }\end{array}$} & \multirow{3}{*}{$\begin{array}{l}\mathrm{t} \\
3.973\end{array}$} & \multirow{3}{*}{$\begin{array}{l}\text { Sig. } \\
.000\end{array}$} \\
\hline & & B & Error & & & \\
\hline & (Constant) & 7.075 & 1.781 & & & \\
\hline & KompetensiKewirausahaan & .404 & .074 & .475 & 5.420 & .000 \\
\hline & PengawasanManajemen & .216 & .063 & .301 & 3.439 & .001 \\
\hline
\end{tabular}

a. Dependent Variable: PerkembanganPerusahaan Sumber : Hasil Penelitian, 2020 ( Data diolah )

Perkembangan Perusahaan $=7,075+$ 0,404 Kompetensi Kewirausahaan + 0,216 Pengawasan Manajemen $+\mathbf{e}$

Makna dari penjelasan analisis regresi linear berganda diatas adalah :

1. 7,075 pada konstanta artinya apabila Kompetensi Kewirausahaan dan Pengawasan Manajemen tidak mengalami peningkatan atau konstanta maka Perkembangan Perusahaan sebesar 7,075 satuan.

2. 0,404 pada koefisien $\mathrm{X} 1$ artinya setiap terjadi peningkatan sebesar satu satuan untuk variabel Kompetensi Kewirausahaan maka Perkembangan Perusahaan sebesar 0,404 satuan dengan anggapan variabel lainnya tetap.

3. 0,216 pada koefisien X2 artinya setiap terjadi peningkatan sebesar satu satuan untuk variabel Pengawasan Manajemen maka Perkembangan Perusahaan sebesar 0,216 satuan dengan anggapan variabel lainnya tetap. 


\section{Uji Signifikan Parsial (Uji t)}

Berikut Tabel hasil pengujian hipotesis secara parsial yaitu :

Tabel 7. Hasil Pengujian Secara Parsial (Uji t)

Coefficients $^{\text {a }}$

\begin{tabular}{|c|c|c|c|c|c|c|}
\hline \multirow{2}{*}{\multicolumn{2}{|c|}{ Model }} & \multicolumn{2}{|c|}{$\begin{array}{c}\text { Unstandardized } \\
\text { Coefficients } \\
\text { Std. }\end{array}$} & \multirow{2}{*}{$\begin{array}{c}\text { Standardized } \\
\text { Coefficients } \\
\text { Beta }\end{array}$} & \multirow[b]{2}{*}{$\mathrm{t}$} & \multirow[b]{2}{*}{ Sig. } \\
\hline & & $\mathrm{B}$ & Error & & & \\
\hline \multirow[t]{3}{*}{1} & (Constant) & 7.075 & 1.781 & & 3.973 & .000 \\
\hline & KompetensiKewirausahaan & .404 & .074 & .475 & 5.420 & .000 \\
\hline & PengawasanManajemen & .216 & .063 & .301 & 3.439 & .00 \\
\hline
\end{tabular}

a. Dependent Variable: PerkembanganPerusahaan Sumber : Hasil Penelitian, 2020 ( Data diolah )

Dari tabel 4.13. diketahui bahwa:

1. Nilai $t_{\text {hitung }}$ untuk variabel Kompetensi Kewirausahaan adalah 5,420 dengan nilai signfiikan sebesar 0,000. Dengan derajat bebas $(\mathrm{df})=\mathrm{n}-\mathrm{k}=91-3=88$ dan taraf $\operatorname{sig} \alpha=$ $0,05 / 2=0,025$, maka nilai $t_{\text {tabel }}$ adalah sebesar 1,987. Oleh karena itu nilai $t_{\text {hitung }}$ $(5,420)>t_{\text {tabel }}(1,987)$ dan sig $0,000<0,025$ maka kriterianya adalah $\mathrm{H}_{0}$ ditolak, $\mathrm{H}_{1}$ diterima sehingga Kompetensi Kewirausahaan secara parsial berpengaruh positif dan signifikan terhadap Perkembangan Perusahaan PT Ekuator Swarna Sekuritas Cabang Medan.

2. Nilai thitung untuk variabel Pengawasan Manajemen adalah 3,439 dengan nilai signfiikan sebesar 0,000. Dengan derajat bebas $(\mathrm{df})=\mathrm{n}-\mathrm{k}=91-3=88$ dan taraf $\operatorname{sig} \alpha=0,05 / 2=$ 0,025 , maka nilai $t_{\text {tabel }}$ adalah sebesar 1,987 . Oleh karena itu $t_{\text {hitung }}(3,439)>t_{\text {tabel }}(1,987)$ dan sig $0,000<0,025$ maka kriterianya adalah $\mathrm{H}_{0}$ ditolak, $\mathrm{H}_{1}$ diterima sehingga Pengawasan Manajemen secara parsial berpengaruh positif dan signifikan terhadap Perkembangan Perusahaan PT Ekuator Swarna Sekuritas Cabang Medan.

\section{Uji Signifikan Simultan (Uji F)}

Berikut Tabel hasil pengujian hipotesis secara simultan yaitu :

Tabel 4.8. Hasil Pengujian Secara Simultan (Uji F)

\begin{tabular}{rlrrrrr}
\multicolumn{7}{c}{ ANOVA $^{\text {a }}$} \\
Model & & Sum of Squares & df & Mean Square & F & Sig. \\
\hline \multirow{3}{*}{1} & Regression & 1105.264 & 2 & 552.632 & 33.244 & $.000^{\mathrm{b}}$ \\
& Residual & 1462.868 & 88 & 16.623 & & \\
& Total & 2568.132 & 90 & & & \\
\hline
\end{tabular}

Dari tabel 4.14. diketahui nilai $\mathrm{F}_{\text {tabel }}$ pada taraf kepercayaan signifikansi 0,05 pada derajat bebas pertama $=\mathrm{k}-1=2$ dan derajat bebas kedua $=\mathrm{n}-\mathrm{k}=88$ adalah 3,10 . Hasil pengujian hipotesis secara simultan bahwa diperoleh nilai $\mathrm{F}$ hitung $(33,244)>\mathrm{F}$ tabel $(3,10)$ dengan nilai signifikansi $0,000<0,05$ maka kriterianya adalah $\mathrm{H}_{0}$ ditolak, $\mathrm{H}_{1}$ diterima sehingga dapat dinyatakan bahwa Kompetensi Kewirausahaan dan Pengawasan Manajemen secara serempak berpengaruh terhadap Perkembangan Perusahaan PT Ekuator Swarna 
Sekuritas Cabang Medan.

\section{Koefisien Determinasi $\left(\mathbf{R}^{2}\right)$}

Hasil pengujian koefisien determinasi dapat dilihat pada Tabel 8. di bawah ini :

Tabel 4.9 Uji Koefisien Determinasi

\begin{tabular}{|c|c|c|c|c|}
\hline \multicolumn{5}{|c|}{ Model Summary $^{\mathbf{b}}$} \\
\hline Model & $\mathrm{R}$ & R Square & Adjusted R Square & Std. Error of the \\
\hline 1 & $.656^{\mathrm{a}}$ & .430 & .417 & 4.077 \\
\hline
\end{tabular}

a. Predictors: (Constant), PengawasanManajemen, KompetensiKewirausahaan

b. Dependent Variable: PerkembanganPerusahaan Sumber: Hasil Penelitian. 2020 (data diolah)

Tabel 9. Besarnya koefisien determinasi yang diperoleh dapat dilihat dari nilai $R$ Square sebesar 0.430 berarti bahwa Kompetensi Kewirausahaan dan Pengawasan Manajemen dapat memberikan kontribusi terhadap Perkembangan Perusahaan PT Ekuator Swarna Sekuritas Cabang Medan sebesar 43\% dan sisanya 57\% dipengaruhi oleh variabel lain di luar dari penelitian ini seperti : transaksi jual beli saham, pelatihan pasar, modal investasi.

\section{Pembahasan}

\section{Pengaruh Kompetensi Kewirausahaan terhadap Perkembangan Perusahaan PT Ekuator Swarna Sekuritas Cabang Medan}

Hasil pengujian secara parsial bahwa adanya pengaruh Kompetensi Kewirausahaan secara positif dan signifikan terhadap Perkembangan Perusahaan PT Ekuator Swarna Sekuritas Cabang Medan. Hasil Penelitian ini sejalan dengan penelitian yang dilakukan oleh Kurniawan (2018) yang berjudul "Pengaruh Kompetensi Kewirausahaan dan Kelanggengan Usaha Terhadap Keunggulan Bersaing" dan Firah (2017) yang berjudul "Pengaruh Kompetensi dan Confidence Investor terhadap Keputusan Investasi Investor Saham di Kota Medan" bahwa Kompetensi Kewirausahaan berpengaruh secara positif dan signifikan terhadap Perkembangan Perusahaan.

\section{Pengaruh Pengawasan Manajemen terhadap Perkembangan Perusahaan PT Ekuator Swarna Sekuritas Cabang Medan}

Hasil pengujian secara parsial bahwa adanya pengaruh Pengawasan Manajemen secara positif dan signifikan terhadap Perkembangan Perusahaan PT Ekuator Swarna Sekuritas Cabang Medan. Hasil Penelitian ini sejalan dengan penelitian yang dilakukan oleh Artanto (2019) yang berjudul "Pengawasan Bapepam terhadap Transaksi Jual Beli Saham di Bursa Efek Indonesia yang Berindikasi Perbuatan Insider Trading” bahwa Pengawasan Manajemen berpengaruh secara positif dan signifikan terhadap Perkembangan Perusahaan.

Pengaruh Kompetensi Kewirausahaan dan Pengawasan Manajemen terhadap Perkembangan Perusahaan PT Ekuator Swarna Sekuritas Cabang Medan 
Berdasarkan hasil uji statistik F yang telah dilakukan dapat diketahui bahwa variabel Kompetensi Kewirausahaan dan Pengawasan Manajemen secara serempak berpengaruh terhadap Perkembangan Perusahaan PT Ekuator Swarna Sekuritas Cabang Medan. Hasil penelitian ini sejalan dengan Kurniawan (2018) yang membuktikan bahwa adanya pengaruh signifikan dari Kompetensi Kewirausahaan terhadap Perkembangan Perusahaan artinya Kompetensi Kewirausahaan yang meningkat memungkinkan Perkembangan Perusahaan meningkat. Serta sejalan dengan penelitian yang dilakukan oleh Artanto (2019) yang membuktikan bahwa Pengawasan Manajemen berpengaruh positif dan signifikan terhadap Perkembangan Perusahaan artinya Pengawasan Manajemen yang meningkat memungkinkan Perkembangan Perusahaan meningkat.

\section{SIMPULAN}

Berdasarkan dari hasil penelitian dan pembahasan sebelumnya, maka dapat disimpulkan bahwa : Kompetensi Kewirausahaan secara parsial memiliki pengaruh positif dan signifikan terhadap Perkembangan Perusahaan PT Ekuator Swarna Sekuritas Cabang Medan. Pengawasan Manajemen secara parsial memiliki pengaruh positif dan signifikan terhadap Perkembangan Perusahaan PT Ekuator Swarna Sekuritas Cabang Medan. Kompetensi Kewirausahaan dan Pengawasan Manajemen secara simultan memiliki pengaruh positif dan signifikan terhadap Perkembangan Perusahaan PT Ekuator Swarna Sekuritas Cabang Medan.

\section{DAFTAR PUSTAKA}

Arifin. 2010. Metode Penelitian Kualitatif, Kuantitatif, dan R \& D. Bandung: Alfabeta.

Handoko, T. Hani. 2014. Manajemen Sumber Daya Manusia. Penerbit BPFE: Yogyakarta. Juhir, Situmorang, Victor M, Jusuf. 2014. Aspek Hukum Pengawasan Melekat. Penerbit Rineka Cipta, Jakarta.

Kadarisman, M. 2012. Manajemen Sumber Daya Manusia , Jakarta: PT. Rajagrafindo. Persada Priansa, Juni Donni. 2016. Perencanaan dan Pengembangan Sumber Daya Manusia.

Penerbit Alfabeta : Bandung.

Primyastanto. 2016. Manajemen Pemasaran Modern. Yogyakarta : Liberty Yogyakarta Sedarmayanti. 2015. Manajemen Sumber Daya Manusia Refromasi Birokrasi dan Manajemen Pegawai Negeri Sipil. Penerbit Refika Aditama, Bandung.

Setyorini, Aniek. 2014. Kewirausahaan. Bogor: IN MEDIA

Setyowati. 2013. Manajemen. Edisi Pertama. Penerbit Prenadamedia Group, Jakarta. Siswandi. 2011. Aplikasi Manajemen Perusahaan:Analisis kasus dan pemecahannya edisi 3, Mitra Wacana Media, Jakarta

Subagyo, Ahmad. 2010, Marketing In Business. edisi pertama, cetakan pertama. Jakarta: Mitra Wacana Media

Sudjatmoko, Adisukarji. 2009. HORIZON IPS. Ghalia Indonesia.

Suwatno, dan Tjutju Yuniarsih. 2016. Manajemen Sumber Daya Manusia. Bandung: Alfabeta. 
Torang, Syamsir.2016. Organisasi dan Manajemen (Perilaku, Struktur, Budaya. \& Perubahan Organisasi. Alfabeta. Bandung.

Widaningsih dan Ariyanti. 2018. Aspek Hukum Kewirausahaan. Malang: Polinema Press. 